\title{
Culture circles on social and environmental determinants: action research with community health agents of Paraisópolis, SP
}

\author{
Círculos de cultura sobre determinantes socioambientais: \\ pesquisa-ação com agentes comunitárias de saúde de Paraisópolis, SP \\ Círculos culturales acerca de determinantes sociales y ambientales: \\ investigación-acción con agentes de salud comunitarios de Paraisópolis, SP
}

\section{Francisco Nilson Paiva dos Santos ${ }^{a}$ Renata Ferraz de Toledo ${ }^{b}$}

\section{How to cite this article:} Santos FNP, Toledo RF. Culture circles on social and environmental determinants: action research with community health agents of Paraisópolis, SP. Rev Gaúcha Enferm. 2020;41:e20190353. doi: https://doi.org/10.1590/19831447.2020 .20190353 a Hospital Israelita Albert Einstein, Unidade Básica de Saúde Paraisópolis II, Instituto Israelita de Responsabilidade Social. São Paulo, São Paulo, Brasil.

' Universidade São Judas Tadeu, Programa de Pós-graduação stricto sensu em Arquitetura e Urbanismo. São Paulo, São Paulo, Brasil.

\section{ABSTRACT}

Objectives: To identify social and environmental determinants of health in the perception of community health agents, and to develop a health education process to contribute to the improvement of health promotion.

Methods: A qualitative action research based on Freire's Research Itinerary (Culture Circles), using talking maps and integrated panels, with 29 community health agents of the Paraisópolis II Basic Health Unit, in the community of Paraisópolis, Sao Paulo. The analysis of the results was carried out by the Method of Triangulation.

Results: Sanitation, housing, behaviors, health services, and other social facilities were identified, which, along with the representation of blaming, were codified and decoded by the integration of technical and traditional knowledge.

Conclusions: Knowledge, values and abilities related to social and environmental determinants and their applicability in the Family Health Strategy, as well as the importance of community strengthening for health promotion and for coping with health vulnerabilities and inequities, were critically unveiled.

Keywords: Community health workers. Social determinants of health. Health education. Family health strategy. Health vulnerability.

\section{RESUMO}

Objetivos: Identificar determinantes socioambientais da saúde, na percepção de agentes comunitárias de saúde, e desenvolver processo de educação em saúde para contribuir no aprimoramento da promoção da saúde.

Métodos: Pesquisa-ação, qualitativa, a partir do Itinerário de Pesquisa de Freire (Círculos de Cultura), utilizando-se de mapafalantes e painéis integrados, com 29 Agentes Comunitárias de Saúde da Unidade Básica de Saúde Paraisópolis II, na comunidade de Paraisópolis, São Paulo. A análise dos resultados deu-se pela Triangulação de Métodos.

Resultados: Saneamento, habitação, comportamentos, serviços de saúde e outros equipamentos sociais foram al guns determinantes identificados, os quais, junto à representação de culpabilização, foram codificados e decodificados pela integração de saberes técnicos e tradicionais.

Conclusões: Conhecimentos, valores e habilidades sobre determinantes socioambientais e sua aplicabilidade na Estratégia Saúde da Família, assim como a importância do fortalecimento comunitário para a promoção da saúde e para 0 enfrentamento de vulnerabilidades e iniquidades em saúde foram desvelados criticamente.

Palavras-chave: Agentes comunitários de saúde. Determinantes sociais da saúde. Educação em saúde. Estratégia saúde da família. Vulnerabilidade em saúde.

\section{RESUMEN}

Objetivos: Identificar los determinantes sociales y ambientales de la salud, en la percepción de los agentes comunitarios de salud, y desarrollar un proceso de educación en salud para contribuir a la mejora de la promoción de la salud.

Métodos: Investigación-acción cualitativa, a partir del Itinerario de Investigación de Freire (Círculos de Cultura), utilizando mapas con voz y paneles integrados, con 29 agentes de salud comunitarios de la Unidad de Salud Básica II de Paraisópolis, en la comunidad de Paraisópolis, San Pablo. El análisis de los resultados se realizó mediante el Método de Triangulación.

Resultados: El saneamiento, la vivienda, los comportamientos, los servicios de salud y otras instalaciones sociales fueron algunos de los determinantes identificados que, junto con la representación de la culpabilización, se codificaron y decodificaron mediante la integración de conocimientos técnicos y tradicionales.

Conclusiones: Se reveló lo siguiente de manera crítica: conocimiento, valores y habilidades sobre los determinantes sociales y ambientales y su aplicabilidad en la estrategia de salud familiar, así como la importancia del empoderamiento de la comunidad para la promoción de la salud y para abordar las vulnerabilidades y las inequidades en salud.

Palabras clave: Agentes comunitarios de salud. Determinantes sociales de la salud. Educación en salud. Estrategia de salud familiar. Vulnerabilidad en salud. 


\section{口INTRODUCTION}

The recognition of the influence of environmental and social aspects on health has been perceived since antiquity, as in the work of Hippocrates "Air, Waters and Places", in 400 B.C., which establishes associations between factors such as water, soil, climate, food, and other customs to justify the emergence of some diseases. The classic studies of John Snow, in the $19^{\text {th }}$ century, which raised suspicions about a possible transmission of cholera by water by mapping cases in the city of London, is another example of this perception about a possible determination of health related to the physical and social environment ${ }^{(1)}$.

However, reflections and actions around what has been called social and environmental determinants of health are more recent and have intensified due to the growing and serious situations of health inequities recognized by the World Health Organization (WHO), especially among the most vulnerable groups. Thus, in 2005, the Commission on Social Determinants of Health (CSDH) was created by the WHO to find out how these determinants operate in the creation of inequities, in order to fight them. With this same concern, in 2006, Brazil created a National Commission on the theme ${ }^{(2)}$.

Health inequities, that is, those systematic differences in health status between different socioeconomic groups, which are socially produced and therefore unfair and changeable ${ }^{(2)}$ are, for the most part, resulting from exposure and overlapping of risks and social exclusion processes, which amplify situations of social and environmental vulnerability, thus hindering or limiting people's ability to react to this scenario of complexity, associated with individual and collective contexts ${ }^{(3-4)}$.

The community of Paraisópolis, locus of this research and located in the south side of the city of São Paulo, is a territory characterized by this scenario of complexity, which combines deficient urban planning, social, and environmental degradation and social exclusion ${ }^{(5)}$. In this area, three Basic Health Units (BHUs) with the Family Health Strategy (FHS) start actions to promote, protect, and recover health.

The potential of health promotion and education actions, with a focus on social and environmental determinants, is highlighted in the National Health Promotion Policy, reviewed in 2014, which recommends the valorization of traditional knowledge through the development of participatory and innovative strategies that favor social mobilization, autonomy, and empowerment ${ }^{(6)}$. Most of these actions are the responsibility of community health agents (CHAs), the protagonists in this action research, whose duties are both collective and individual and are performed in the context of the domicile or assigned territory of the reference $\mathrm{BHU}^{(7)}$
At the same time that the CHAs' potential to develop these actions is recognized, the countless daily challenges for their effectiveness are well-known.

This view of the social and environmental determinants of health in the context of health promotion is also a concern of the Territorial Laboratory in Manguinhos (Laboratório Territorial de Manguinhos, LTM), which, since 2002, has been developing integrated actions among researchers from the Fiocruz foundation and other institutions with favela residents in Rio de Janeiro (Manguinhos, Alemão, and Rocinha), which was called "expanded communities of action research", with the FHS as one of the population's care references ${ }^{(8)}$.

Despite the undeniable relevance of the FHS and the work of the CHAs for a better understanding of the social and environmental determinants of health, especially for tackling health inequities, there are few studies with this focus. In addition, a mapping of research studies on social determinants of health in Brazil concluded that, in general, the results of this production still have a very limited practical reach, with little interference in public health promotion policies, which, according to the authors, demands, on its turn, the expansion of participatory research, involving non-academic actors ${ }^{(9)}$.

Thus, the relevance of methodological approaches and participatory instruments, such as Freire's Research Itinerary and his Culture Circles, as well as the action research itself, in the face of realities and issues involving complexity, uncertainties and decision making, was already evidenced by several authors for favoring dialog, critical reflection, and the shared production of knowledge $\mathrm{e}^{(10-14)}$.

In this context, this research aimed to identify social and environmental determinants of health in the perception of community health agents, and to develop a health education process to contribute to the improvement of health promotion.

\section{METHODOLOGY}

This research was carried out in the community of Paraisópolis, in the south side of the city of São Paulo, Morumbi neighborhood. About 60 thousand inhabitants live in that place, in different types of housings (the majority made of masonry), and have an irregular real estate status. The absence of urban planning, as well as adequate sanitation services, are some of the social and environmental problems faced by the local residents, which contribute to expanding situations of social inequality, exposure to risks, and social and environmental vulnerability ${ }^{(5)}$.

This work is an action research ${ }^{(10,14)}$ with a qualitative approach ${ }^{(15)}$, conducted based on the theoretical and methodological framework of Paulo Freire: the Culture Circles and his Research Itinerary(11). 
Action research means a methodological approach of Community Based Participatory Research (CBPR) ${ }^{(12)}$ with direct involvement of the investigated individuals in all the stages. During this process of research and action, reflections are promoted and new knowledge is built in a collaborative way between researchers and research participants, based on demands perceived during the research ${ }^{(10,14)}$.

Dialog, participation, and critical reflection contextualized in the investigated universe are also principles of Freire's Research Itinerary ${ }^{(11)}$. Thus, it was decided to hold meetings in this action research in the format of Culture Circles, in order to achieve the objectives proposed for the stages of: thematic research, that is, survey of generating themes considered a starting point for the socio-educational process; coding and decoding, to problematize them, seeking meanings and knowledge in the experienced reality, integrating them with technical and scientific knowledge; and critical unveiling, aimed at raising awareness and producing new values, knowledge and practices ${ }^{(11,16)}$. Several participatory research and intervention instruments, through which the investigated individuals and the researcher interact directly, were used, such as the creation of talking maps and integrating panels, simultaneously favoring reflection, dialog, collective production of graphic representations and narratives (in the form of drawings and answers), as well as collaborative learning processes ${ }^{(14)}$.

29 CHAs participated in the Culture Circles, held in four monthly meetings, between February and May 2019, from the 6 FHS teams of the II BHU of Paraisópolis, the following being considered as inclusion criteria: working as a $\mathrm{CHA}$ in that BHU and living in Paraisópolis for at least 1 year; and, as exclusion criteria, not working at that moment due to vacation or to being on leave. All the meetings took place at the II BHU of Paraisópolis and started with a community breakfast for reception and welcoming. The investigation and action themes and techniques used in each meeting were defined according to the demands felt during the process, as expected from an action research and from the Culture Circles since they are open and adaptive methodological approaches ${ }^{(10-14)}$. For this reason, it was decided to describe the meetings and the chain of instruments and techniques used in this Itinerary together with the presentation of the results of this research, in order to highlight the open and adaptive process of an action research.

The analysis of the results was carried out using the Method of Triangulation, indicated for qualitative studies that combine different research instruments. Based on the organization and description of the results produced by the participants, using each instrument applied, they were analyzed and interpreted in an integrated manner, minimizing bias and favoring broader and more contextualized views regarding the different aspects of the investigated reality. This joint analysis of the instruments, in a dialectical process, enabled the recognition of new demands and possibilities of action ${ }^{(17)}$.

The research was duly authorized by the Research Ethics Committee (CAAE: 83713718.2.3001.0086); all the participants signed a Free and Informed Consent Form (FICF) and had their identities kept confidential, by not revealing their names or faces. In addition, all the drawings and statements presented are the result of collective production by the CHAs.

\section{RESULTS AND DISCUSSION}

The first meeting with the CHAs was held on February $19^{\text {th }}, 2019$, lasting 2 hours, for general clarifications on the topic of social and environmental health determinants and research objectives, as well as for raising expectations. It is important to highlight that the researcher in charge of this action research was also a nurse coordinator of one of the FHS teams at the II BHU of Paraisópolis, working there since 2012, and therefore already developing continuing education actions and health education and promotion projects with these CHAs. In this way, the pre-existence of the bond and trust between the researcher and the CHAs participating in the research, which is essential in action research processes and Culture Circles, was taken into account. 25 CHAs were present at this first meeting, which was a conversation circle. All of them showed interest, both in relation to the research topic, for the possibility of getting to know it better, and by the proposal to create spaces for dialog favored by the Culture Circles, through which they could give voice to their ideas and be protagonists of possible changes. At this same meeting, they read and signed the FICF, and the date of the next meeting was agreed upon.

The second meeting took place on March 12 $2^{\text {th }}, 2019$, lasted 4 hours, had the participation of $22 \mathrm{CHAs}$, and was divided into two moments. Following Freire's Research Itinerary ${ }^{(11)}$, it was sought at the first moment, which is considered a moment of thematic investigation, to recognize the themes generating this action research process, using the taking-map technique, a graphic representation of a given reality, which must be built collectively, followed by the presentation of what was reflected and produced ${ }^{(14)}$. The participants, divided into 6 groups, were then invited to write in the previously printed maps of their areas of activity in the territory of the II BHU Paraisópolis, social and environmental factors that, in their opinion, had a negative or positive influence on the local inhabitants' health. 
It is clarified that the expression'social and environmental factors' was used to guide the performance of this activity because it is easier to understand, in this initial moment, than the expression'social and environmental determinants of health.' It was also decided not to form separate groups according to the FHS teams, since all the CHAs were residents of the territory, favoring the integration of representations built both from professional experiences in the respective areas, as well as from daily experiences in the place.

Figure 1 shows clippings of the talking maps, and Chart 1 shows the social and environmental factors with a negative and positive influence on health, represented in the maps and mentioned in their presentation, grouped into categories of generating themes.

These aspects, both negative and positive, indicated by the $\mathrm{CHAs}$ are also evidenced in the literature as determinants with direct and indirect influence on health, based on the different living conditions, that is, the ways in which individuals are born, grow, live and age ${ }^{(1-2)}$. It is worth highlighting the several positive aspects also recognized by the CHAs as achievements of the community itself in social struggle processes, which, in the authors' interpretation, contribute to coping with adverse situations in the local daily life. In other words, in this context of vulnerability and scarcity, evidenced by the negative factors represented by the CHAs, this ability to self-organize and also to value positive determinants, such as local social facilities, among others, demonstrates the recognition of alternatives to deal with problems, opposing what is thought to be an exclusively chaotic place ${ }^{(13)}$.

Continuing this second meeting, the participants sought, at the second moment, to recognize some aspects (generating themes) that were common to the groups in order to start the deepening of reflections and discussions about them, to codify the reality experienced by the CHAs and decode it from the notion of social and environmental determinants of health, according to Freire's Research Itinerary ${ }^{(11)}$. For this, after selecting some priority aspects, in agreement with the CHAs, 5 questions were formulated to be reflected upon and answered using the Integrated Panel technique. It helps to diagnose and assess previous knowledge that, due to its dialogical and participatory nature, also contributes to the production of new knowledge in a collaborative way ${ }^{(14)}$. For this activity, the participants were divided into small groups to answer the proposed questions. Each group received a different question and, after 5 to 10 minutes, the papers were exchanged, until all the groups answered all the questions, in a complementary way.

The following questions were proposed for this Integrated Panel: Why did creeks influence the health of the territory?; Why did abandoned animals influence the health of the territory?; Why did garbage interfere with health?; How did social and environmental determinants interfere with the residents' mental health?; and How did drugs interfere with health?

It was decided to start this process of encoding and decoding from guiding questions, in accordance with the principles of Freire's pedagogy and his Research Itinerary, which suggests the promotion of reflections, preferably from questions and not from answers or solutions ${ }^{(11)}$.

Regarding the influence of the creeks on health, one of the collectively constructed answers said:

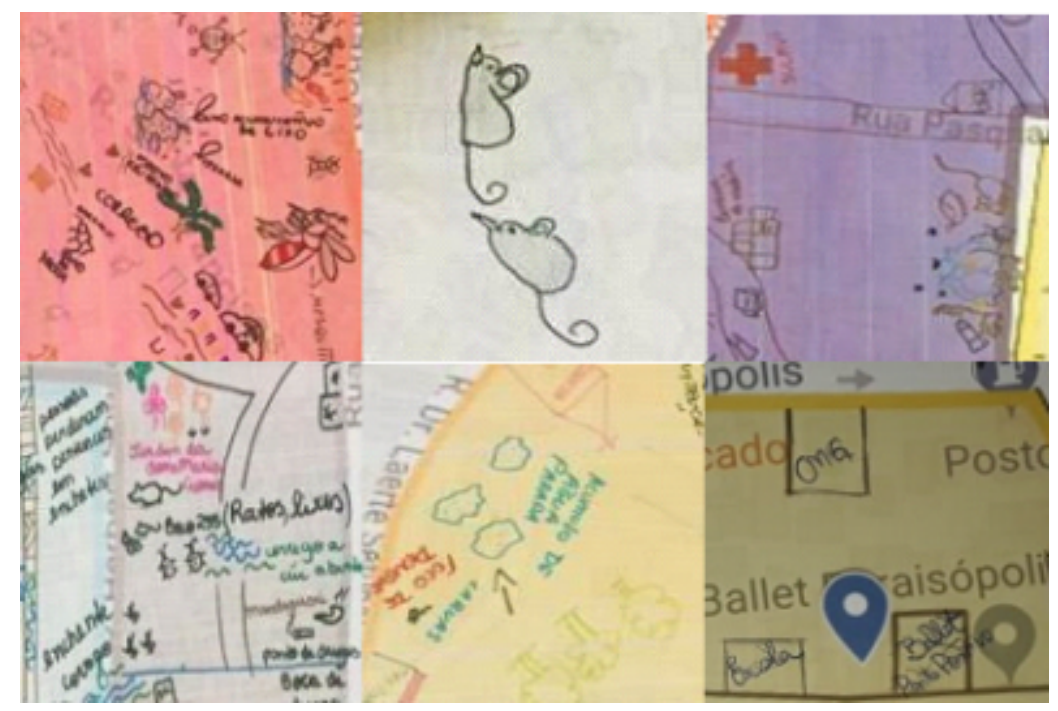

Figure 1 - Clippings of the talking maps produced by the CHAs: thematic investigation on social and environmental determinants of health, 2019

Source: Research data, 2019. 


\begin{tabular}{|c|c|}
\hline Categories of generating themes & $\begin{array}{l}\text { Negative social and environmental factors } \\
\text { represented and/or mentioned }\end{array}$ \\
\hline Inefficient sanitation & $\begin{array}{l}\text { Garbage in inappropriate places; open sewage; creeks } \\
\text { with waste and sewage; clogged storm drains; bad smell. }\end{array}$ \\
\hline Animals & $\begin{array}{l}\text { Abandoned animals; animals inside homes; disease } \\
\text { vectors in animals (rats, cockroaches, flies, mosquitoes). }\end{array}$ \\
\hline Housing and other facilities & $\begin{array}{l}\text { Wooden shacks; houses very close to each other; } \\
\text { humidity inside homes; electric "cats" (electricity theft); } \\
\text { wooden bridge; junkyard. }\end{array}$ \\
\hline Social issues/violence & Drugs (consumption and trafficking); bars; sexual abuse. \\
\hline Behavioral factors & $\begin{array}{l}\text { Neglect of the community; people's "ignorance" (little } \\
\text { knowledge and/or difficulty in learning); cars parked } \\
\text { on the sidewalks; loud car sounds late at night; people } \\
\text { accumulating garbage. }\end{array}$ \\
\hline Categories of generating themes & $\begin{array}{l}\text { Positive social and environmental factors } \\
\text { represented and/or mentioned }\end{array}$ \\
\hline Trade & $\begin{array}{l}\text { Butchery; bakery; pizzeria; restaurants; stores; market; } \\
\text { drugstore; fuel station; bar; bank. }\end{array}$ \\
\hline Health services & $\begin{array}{l}\text { Basic Health Unit - BHU; Specialty Outpatient } \\
\text { Clinic - SOC; dentist; CHA; Outpatient Medical } \\
\text { Assistance - OMA; Psychosocial Care Center - CAPS. }\end{array}$ \\
\hline NGOs/Social projects & $\begin{array}{l}\text { Bom Prato ("Good Plate"); Reference Center for Social } \\
\text { Assistance (CRAS), and Casa da Mulher ("The Woman's } \\
\text { Place"); Recycling Center. }\end{array}$ \\
\hline Sports and leisure & Ballet school; sports court; soccer field; gym. \\
\hline Green areas & Houses' gardens; trees. \\
\hline Education & $\begin{array}{l}\text { School;"mãe crecheira" ("nursery mother"); } \\
\text { language school. }\end{array}$ \\
\hline Behavioral factors & Receptive patients \\
\hline Animals & The pleasant company of pets. \\
\hline Churches & Space to socialize and "spiritual food". \\
\hline
\end{tabular}

Chart 1 - Social and environmental factors with a negative and positive influence on health, grouped into categories of generating themes, according to the talking maps: thematic investigation, 2019 Source: Research data, 2019.

Due to several factors, one of them is the infiltration of the houses that are built on top of the creek; it interferes with the accumulation of garbage, because they think they can dispose everything there. If we are not in a clean environment, we are at risk of getting an infection (collective production of the $\mathrm{CHAs}$ ).
Regarding the abandonment of animals, in general, the highlights were the following: the lack of commitment to the animals, not vaccinating or neutering them; risk of bites; odors from urine and feces; ill-treatment; scabies, ticks, and fleas.

Regarding the interference of garbage on health, the CHAs reflected and registered on the panel that: 
Garbage attracts animals, such as mice and cockroaches, increases the risk of accidents, as after the funk dance many glass bottles are exposed and broken. Lack of selective collection or recycling, which causes environmental damage. Lack of garbage dumpsters. Also with regard to the population, there is lack of awareness regarding disposal (collective production of the CHAs).

In fact, environmental factors, as recognized in this codification process by the CHAs through the Integrated Panel, are responsible for several diseases and deaths around the world. It is called the environmental burden of the disease. There are estimates that 23\% of the global deaths and 22\% of the disability adjusted life years (DALY) are associated with environmental factors. In addition, about a quarter of this global disease burden can be avoided by reducing environmental risks ${ }^{(18)}$.

Another question proposed for reflection was how the social and environmental determinants could interfere with the residents' mental health. The CHAs remembered and registered possibilities of:

Causing depression, anxiety and powerlessness, by not being able to do anything about it. Limitation to act in the situation. The social and environmental determinants can aggravate mental disorders, and even create addictions related to the environment where they live; if the individual lives in the midst of garbage or drug traffic, the noise causes problems. They end up accumulating waste, which interferes with their mental health, causing a dependence on accumulating unnecessary things (collective production of the CHAs).

As to the influence of drugs on health, aspects related to violence, fear, security, the right to move freely, family breakdown, and dependence were associated, as well as theft, assaults, physical and psychological aggressions; deaths of users and innocents; sexual abuse; mental disorders; unemployment; and transmission of diseases (AIDS, tuberculosis). It was also remembered that:

Drug traffic interferes with the work of health professionals (collective production of the CHAs).

During the discussion of the Integrated Panel, it was evident in the authors'interpretation, among other aspects, the CHAs' act of blaming (codification) the community, as they repeatedly reported that their knowledge and information they "passed on" were almost always ignored by the community, which continued to act inappropriately and, consequently, suffering, for example, from the disposal of garbage and dump in creeks. Blaming was also coded based on generating themes recognized in this process, represented in the talking maps and in the integrated panel:

\section{Neglect of the community (collective production of} the CHAs).

People's ignorance due to little knowledge or difficulty in learning (collective production of the CHAs).

Thus, considering the formative potential of the Culture Circles and of the action research, it was decided to better explore this matter in subsequent meetings, in accordance with the cyclical and adaptive process of the action research, based on reflections on traditional and critical health education methods and practices.

The third meeting was held on April 2 ${ }^{\text {nd }}, 2019$, lasting 4 hours and attended by $22 \mathrm{CHAs}$. In order to stimulate reflections and dialog on blaming, codified in the previous meeting, and to decode it based on the construction of knowledge about the characteristics and principles of traditional and critical health education practices, the Integrated Panel technique was used again, with the following guiding questions: What is education?; What is health?; What is health promotion?; and, What is health education? Then 4 groups were formed and the participants were able to reflect, discuss and engage in a social learning process on the topic (coding and decoding).

With regard to education, the CHAs considered and registered in the panel that:

It is a way of integrating individuals into society. It means respecting others and their differences; it involves more than knowledge, it also includes what is done with such knowledge and how it is passed on. Instructing knowledge. Respecting diversity. Empathizing with everyone. Searching for the best way to guide, speak the same 'anguage' (collective production of the CHAs).

Although some of the CHAs' education representations show certain concern with the behavioral component, on the other hand, the three dimensions of education (cognitive, affective, and psychomotor) were verified, that is, their importance both in the construction of knowledge and of values and skills, with an emphasis on valuing respect, empathy, diversity, local knowledge, and the applicability of education, which are fundamental elements to qualify the work of the CHAs in the context of the FHS $(6,11,13,19)$.

As regards health, they concluded that: 
It is caring for the body and for the mind. Being happy and grateful for everything they already have. It is when the body and the mind are functioning properly, in harmony and with good quality of life. It means having access to education, food, housing, sanitation, medical care. It is the physical, psychological and social condition of the individuals in society, respecting their integrality, equity and universality (collective production of the $\mathrm{CHAs}$ ).

Accordingly, it is possible to perceive in these representations of health a very broad understanding by the CHAs, which, of course, surpasses, in the authors' opinion, any reductionist association with the absence of diseases, incorporating several social and environmental determinants (as well as individual, social, and macro-structural elements) and its importance for the integral development of the human being ${ }^{(2,6)}$.

Regarding health promotion, they highlighted the following:

Promoting well-being. Preventing physical and mental illness. Leisure. CHA visits and BHU monitoring. Informing the patients about diseases, vaccines, health risks, access to the medical appointment. Promoting actions inside and outside the community in a preventive way to raise awareness, that is: changing the act of raising awareness and starting actions in the territory. It involves including the patients in the care, and drawing their attention to information that can save their lives. Raising awareness of good habits, such as healthy eating, recycling, among others. Promoting spaces for improvement, both in the environment and in people themselves (collective production of the $\mathrm{CHAs}$ ).

In this case, the understanding of disease prevention and health promotion as synonyms $s^{(6)}$ was verified in the representations of this panel, as well as the presence of a passive and unidirectional attitude, in the sense that'I know what's best for you', which can be reflected, in the authors'interpretation and, as already mentioned, on the exclusive blaming of individuals and social groups for their health problems ${ }^{(19)}$. In turn, it were also evident in some representations of health promotion both the relevance of social and environmental determinants ${ }^{(2)}$ and the overcoming (decoding) of this act of blaming, even though it is still under construction in this Research Itinerary (11).

Regarding health education, the CHAs concluded that:

It is to promote actions that offer guidance and benefits to make the population aware of the correct way to take care of themselves. It involves passing on something or some knowledge that is new to many people, but in a simple and easy to understand way. Educating takes into account the experience of each individual. Knowing how to listen and absorb the guidance given by the health professionals, in addition to improving knowledge so that patients understand the importance of taking care of their own health (collective production of the CHAs).

Thus, based on this prior knowledge, reflections on traditional health education practices (health education) and critical health education practices (public health education) were stimulated. Therefore, it was discussed with the CHAs that blaming people for risky behaviors considered inappropriate tends to isolate components and disregard the variability, complexity, and dynamics of the social practices. In this case, the chances of becoming ill are only related to the individual component, for example, access to information and its appropriation. On the other hand, by considering in the health education practices the various conditions of vulnerability (such as individual, social, and pragmatic/institutional conditions), this view previously focused on risk behaviors is broadened, understanding that the chances of falling ill can, in fact, be related to the various social and environmental determinants of health and their interrelationships ${ }^{(19)}$, seeking, in this way, to overcome with the CHAs the act of blaming, moving from codification towards decoding.

This debate also allowed for clarifications based on the Diagram proposed by Dahlgren and Whitehead, which was printed and distributed to the $\mathrm{CHAs}$, to represent the social and environmental determinants in different layers or levels: individual, such as age, gender and hereditary factors; social, related to living and working conditions, such as access to sanitation, education, food, etc.; and macro-structural, that is, the general social, political, economic, and cultural conditions ${ }^{(2)}$.

The visualization of the Diagram by the CHAs also made it possible to reflect that, although the many social and environmental determinants were represented in layers or levels, they were interrelated and could overlap in many situations, such as in the context of Paraisópolis, increasing exposure to risks and social and environmental vulnerability ${ }^{(3-4)}$. In this way, there was also a discussion about the impact that education and health promotion actions could have by focusing on individual determinants, favoring, for example, healthier choices; on social determinants, expanding or qualifying access to services; or on macro-structural determinants, directly influencing public policies ${ }^{(2)}$.

The CHAs also associated exhaustive working hours and, consequently, lack of time, to justify difficulties in carrying 
out activities that incorporated social and environmental determinants in health, as well as in other health promotion activities. They also stated that the acting styles of the six FHS teams diverged and that this more participatory form of approach, like the Culture Circle itself, facilitated the approach and the bond with the community, since, in this way, knowledge was produced by valuing everyone's knowledge ${ }^{(11,16)}$.

As an example, they mentioned that, on one occasion, when actions were taken to revitalize areas where there were garbage spots in the community, there was no adequate educational process, as the residents of that place indicated, according to the CHAs, other places for garbage disposal, on nearby streets. They also spoke of the importance of public policies, political awareness, and social organization and mobilization, both by the community and by the health workers, in order to participate in the planning of actions aimed at improving local, social, and environmental conditions with an impact on the residents' health. This thinking is in line with the principles advocated by the National Health Promotion Policy, regarding the valuation of social participation, inter-sectoriality, sustainability, and territoriality, among others, for the development of actions in the fields of education and health promotion ${ }^{(6)}$, as well as with regard to the social role of the attributions of the $\mathrm{CHA}^{(7)}$.

On May $14^{\text {th }}, 2019,29$ CHAs met again at the II BHU of Paraisópolis for another Culture Circle, which lasted 4 hours. Continuing with the phases of Freire's Research Itinerary (11), this fourth meeting sought to both promote critical unveiling and recognize it throughout the entire action research process. To this end, the CHAs were invited to reflect on the following guiding question: "What do we learn?"

At first, they thought and answered individually in forms provided by the researcher, where they reported lessons related to the better identification of vulnerable places, the importance of respecting different values and cultures, aspects of citizenship, and the power of social mobilization, among others.

Subsequently, gathered in 5 random groups, the CHAs collectively formulated a single answer to this same question, reaching a consensus, based on individual opinions, which could, of course, be reconstructed and reframed in the groups (Chart 2).

The authors were compelled by the presence, in the answers, of feelings and lessons about the importance of empowerment, that is, empowering individuals as social subjects, as well as shared responsibility and respect for the "other", with their values and knowledge, pursuant to health promotion principles and for a more qualified work in the Paraisópolis territory(6).

Still with the purpose of stimulating and recognizing other possible critical unveilings of this process, the researcher then proposed reflections on "How can we change our health education practices, in order to better incorporate the approach to social and environmental determinants of health?"

The CHAs stressed that it is necessary to recognize other voices and listen to them because, when the health education

\begin{tabular}{|c|c|}
\hline Group & What we learn \\
\hline 1 & $\begin{array}{l}\text { Together we learned the importance of listening, of respect, ethics, confidentiality, continuous learning, so that } \\
\text { we can improve our community and work environment. }\end{array}$ \\
\hline 2 & Together we can make the population aware, so that everyone can do their part, taking care of the environment. \\
\hline 3 & $\begin{array}{l}\text { Despite all the needs, we know that we cannot do it alone, and together with the community we are stronger to } \\
\text { fight for improvement. }\end{array}$ \\
\hline 4 & $\begin{array}{l}\text { We learned to observe and guide according to the specific economic and cultural reality and to the belief of each } \\
\text { person. With listening and an enlarged look with empathy. }\end{array}$ \\
\hline 5 & $\begin{array}{l}\text { We learned that as individuals we can make a difference or change things around us and, in addition, we learned } \\
\text { where to start those changes, and how to continue them. We learned to respect each other's time and especially } \\
\text { the "no" answer from people around us. }\end{array}$ \\
\hline
\end{tabular}

Chart 2 - Answers collectively formulated by the CHAS in each group about "what do we learn?": critical unveiling, 2019 Source: Research data, 2019. 
process is based on listening and valuing the voice of others, the information and knowledge produced are consolidated, as there is an exchange based on critical reflection. On the other hand, when activities are carried out unilaterally, with the health team simply providing a solution to the community, in most cases, the residents do not participate in this educational process ${ }^{(11,19)}$. Thus, it became evident, especially in the last meeting, that such pre-existing blaming among the participants suffered a transformation during the Research Itinerary.

Still with the concern to reflect and qualify the health education practices developed by the CHAs, focusing on the social and environmental determinants of health, at the end of the fourth meeting, a proposal was made to scan the talking maps created by them. This is the technique of the Participative GIS (or Geographic Information System) with Public Participation, widely used as support for action planning and decision making. By incorporating public participation in the use of this tool, integrating technology, technical knowledge and traditional local knowledge, it contributes to empowerment, social learning and to better management processes in the territory ${ }^{(20)}$, which match the demands of this research, in the context of the FHS and of situations of social and environmental vulnerability.

The CHAs considered it a positive proposal, as they believed in the possibility of this instrument to facilitate the identification, visualization, and understanding of problems in broader contexts, often experienced collectively by the residents, thus also contributing to increase the sense of shared responsibility.

At the end of this meeting, the researcher also asked the CHAs to express, without identifying themselves, the process experienced up to that moment with a single word, namely:

Productive. Knowledge. Participative. Exchange of experiences. Communication. Wisdom. Learning. Respect. Culture. Teamwork. Change now. Awareness raising. Empathy. Improvements. Humanization. Hope. Listening. Union. Productivity. Hearing. Reflection. We are stronger together. Transformation. Flexibility. Focus. Availability. Willingness. Time. Loveliness.

These expressions revealed and demonstrated the potential of this critical unveiling process, experienced by the $\mathrm{CHAs}$ and by the researcher, during the Culture Circles and the action research. Knowledge, values, and skills were built and reframed in a collaborative and dialogical way, in the hope that they may be strengthened and improved in the continuity of the practices of education and health promotion by these FHS teams, at the II BHU of Paraisópolis, now with an expanded look at social and environmental determinants and their influence on the health and quality of life of the local community.

\section{FINAL CONSIDERATIONS}

As limitations of this research, the participation of $\mathrm{CHAs}$ from only one $\mathrm{BHU}$, operating in a very specific territory, is recognized; therefore, not allowing for the generalization of the results, even in similar contexts, in accordance with qualitative studies. In turn, it is considered that the reflections proposed, as well as the collaborative knowledge produced through the action research, have a major contribution to university teaching, research, and extension (as well as to the work of nurses and other areas of health), and assistance and/or management activities, based on the knowledge produced in the theoretical and conceptual field of social and environmental determinants of health, education, and health promotion and, especially, in the methodological field, by highlighting the investigative and socio-educational potential of the combination of the Culture Circles to action research ${ }^{(16)}$.

Thus, it is concluded that this action research, developed according to Freire's Research Itinerary (the Culture Circles) and analyzed by the Methods of Triangulation, that is, by the integrated interpretation of the results by the different instruments of investigation and intervention, allowed for the identification of social and environmental determinants of health in the perception of the CHAs, who worked in the FHS of the II BHU of Paraisópolis, among which the following stood out: absence or inefficiency of sanitation, abandonment of animals, and presence of disease vectors, unhealthy housing, violence, and behavioral factors. The CHAs also valued several positive aspects, such as the health services, projects, and other social facilities that offer sports, culture and leisure, a result of the community's own achievements.

Concurrently with the recognition of these social and environmental determinants, a shared health education process was developed, through which the stages of thematic investigation, coding and decoding, and critical unveiling occurred, in some situations, jointly and simultaneously, favoring the integration of technical and traditional local knowledge in a dialogical and reflective way, as expected from an action research and Freire's Research Itinerary.

In turn, this critical unveiling evidenced among other ways in the representations of empowerment and empathy manifested by the CHAs may contribute to qualify the practices of education and health promotion in the territory of Paraisópolis, where, despite so many situations of social and environmental vulnerability and health inequities, there 
is a strong human potential to face and transform these adverse contexts. This potential is added to the notable appreciation of the role of the CHAs in Primary Health Care as a public policy of great relevance, capable of contributing to overcome the necessary rupture with the exclusionary and productivist health logic.

It is also expected that these reflections are strengthened and reinforced in the process of continuing education of the CHAs, in partnership with the health professionals of the II BHU of Paraisópolis, professionals among whom is the main researcher of this study.

\section{REFERENCES}

1. Sobral A, Freitas CM. [Model of organization of indicators for operationalizing the social-environmental determinants of health]. Saúde Soc. 2010;19(1):3547. Portuguese. doi: https://doi.org/10.1590/S0104-12902010000100004

2. Comissão Nacional sobre Determinantes Sociais da Saúde (BR). As causas sociais das iniquidades em saúde no Brasil: relatório final da Comissão Nacional sobre Determinantes Sociais da Saúde. Rio de Janeiro: Fiocruz; 2008 [citado 2019 out 20]. Disponivel em: http://bvsms.saude.gov.br/bvs/publicacoes/ causas_sociais_iniquidades.pdf

3. Lapola DM, Braga DR, Di Giulio GM, Torres RR, Vasconcellos MP. Heat stress vulnerability and risk at the (super) local scale in six Brazilian capitals. Clim Change, 2019;154(3-4):477-92. doi: https://doi.org/10.1007/s10584-019-02459-w

4. Carmo ME, Guizardi FL. [The concept of vulnerability and its meanings for public policies in health and social welfare]. Cad Saúde Pública, 2018;34(3):e00101417. Portuguese. doi: https://doi.org/10.1590/0102-311X00101417

5. Maziviero MC, Silva AS. [The case of the Paraisópolis Complex management: conceptual differences of the slums intervention programs in São Paulo]. Urbe Rev Bras Gest Urbana 2018;10(3):500-20. Portuguese. doi: https://doi. org/10.1590/2175-3369.010.003.a003

6. Ministério da Saúde (BR). Secretaria de Vigilância em Saúde. Secretaria de Atenção à Saúde. Política Nacional de Promoção da Saúde: PNPS: revisão da Portaria MS/GM nº 687, de 30 de março de 2006. Brasília: Ministério da Saúde; 2015 [citado 2019 out 10]. Disponível em: http://bvsms.saude.gov.br/bvs/ publicacoes/pnps_revisao_portaria_687.pdf

7. Presidência da República (BR). Lei № 13.595, de 5 de janeiro de 2018. Altera a Lei no 11.350, de 5 de outubro de 2006, para dispor sobre a reformulação das atribuições, a jornada e as condições de trabalho, o grau de formação profissional, os cursos de formação técnica e continuada e a indenização de transporte dos profissionais Agentes Comunitários de Saúde e Agentes de Combate às Endemias. Brasilia; 2018 [citado 2019 out 10]. Disponível em: http://www. planalto.gov.br/ccivil_03/_Ato2015-2018/2018/Lei/L13595.htm\#art1
8. Porto MFS, Cunha MB, Pivetta F, Zancan L, Freitas JD. [Health and environment in the slums: thoughts to foster emancipatory promotion of health]. Serv Soc Soc. 2015;(123):523-43. Portuguese. doi: https://doi.org/ 10.1590/0101-6628.035

9. Borde E, Akerman M, Pellegrini Filho A. Mapping of capacities for research on healthandits social determinantsin Brazil. CadSaúdePública,2014;30(10):208191. doi: https://doi.org/10.1590/0102-311X00162513

10. Machado GCXMP, Maciel TMFB, Thiollent M. Uma abordagem integral para saneamento ecológico em comunidades tradicionais e rurais. Cienc Saude Coletiva, 2019. [citado 2019 out 10]. Disponível em: http://www. cienciaesaudecoletiva.com.br/artigos/uma-abordagem-integral-parasaneamento-ecologico-em-comunidades-tradicionais-e-rurais/17291

11. Freire P. Pedagogia do oprimido. 64a ed. Rio de Janeiro: Paz e Terra; 2017.

12. Wallerstein N, Duran B, Oetzel J, Minkler M. Community based participatory research for health: advancing social and health equity. 3rd ed. San Francisco, CA: Wiley and Sons; 2017.

13. Giatti LL. 0 caráter adaptativo da pesquisa participativa: rompendo com a monocultura de saberes. In: Toledo RF, Rosa, TEC, Keinert, TM, Cortizo, CT. Pesquisa Participativa em Saúde: Vertentes e Veredas. São Paulo: Instituto de Saúde, 2018 [citado 2019 out 15]. p.47-61. Disponível em: http://www.saude. sp.gov.br/resources/instituto-de-saude/homepage/temas-saude-coletiva/ metodologias_participativas_final.pdf

14. Toledo RF, Giatti LL. Challenges to participation in action research. Health Promot Int. 2015;30(1):162-73. doi: https://doi.org/10.1093/heapro/dau079

15. Minayo, MCS. Amostragem e saturação em pesquisa qualitativa: consensos e controvérsias. Rev Pesq Qualitat. 2017 [citado 2019 out 15];5(7):1-12. Disponível em: https://editora.sepq.org.br/index.php/rpq/article/view/82

16. Garzon AMM, Silva KL, Marques RC. Liberating critical pedagogy of Paulo Freire in the scientific production of Nursing 1990-2017. Rev Bras Enferm. 2018;71 (suppl. 4):1854-61. doi: https://doi.org/10.1590/0034-7167-2017-0699

17. Santos KS, Ribeiro MC, Queiroga DEU, Silva IAP, Ferreira SMS. The use of multiple triangulations as a validation strategy in a qualitative study. Cienc Saúde Coletiva. 2018;25(2):655-64. doi: https://doi.org/10.1590/ 1413-81232020252.12302018

18. Prüss-Ustün A, Wolf, J, Corvalán C, Neville T, Bos R., Neira M. Diseases due to unhealthy environments: an updated estimate of the global burden of disease attributable to environmental determinants of health. J Public Health. 2017;39(3):464-75. doi: https://doi.org/10.1093/pubmed/fdw085

19. Sevalho G. 0 conceito de vulnerabilidade e a educação em saúde fundamentada em Paulo Freire. Interface (Botucatu). 2018;22(64):177-88. doi: https://doi. org/10.1590/1807-57622016.0822

20. Carvalho CM, Giatti LL. Participatory GIS for urban sustainability and resilience: a perspective of social learning and ecology of knowledge. In: Azeiteiro U, Akerman M, Leal Filho W, Setti A, Brandli L, editors. Lifelong learning and education in healthy and sustainable cities. Springer: Cham; 2018. p.21-34. World Sustainability Series. doi: https://doi.org/10.1007/978-3-319-69474-0_2

\section{- Corresponding author:}

Francisco Nilson Paiva dos Santos

E-mail: franpaivasantos1975@gmail.com

\section{Associate editor: \\ Cecília Helena Glanzner}

Received: 11.05.2019

Editor-in-chief:

Approved: 04.01.2020

Maria da Graça Oliveira Crossetti 